УДК 629.04.001

\title{
МЕТОДИЧНІ ЗАСАДИ ВИЗНАЧЕННЯ ПАСИВНОЇ БЕЗПЕКИ КУЗОВНИХ КОНСТРУКЦЙ КОЛІСНИХ ТРАНСПОРТНИХ ЗАСОБІВ
}

\author{
Іван Роговський \\ Національний університет біоресурсів і природокористування України, \\ вул. Героїв Оборони, 15, м. Київ, Україна, \\ e-mail:rogovskii@nubip.edu.ua
}

https://doi.org/10.31734/agroengineering2021.25.189

\begin{abstract}
Роговський І. Методичні засади визначення пасивної безпеки кузовних конструкцій колісних транспортних засобів

У статті викладено вдосконалення методичних засад визначення пасивної безпеки кузовних конструкцій колісних транспортних засобів завдяки застосуванню методу кінцевих елементів. Відповідно до методології пасивна безпека колісних транспортних засобів значною мірою забезпечується конструкцією їхніх кузовів та кабін. Саме вони сприяють поглинанню основної частини енергї̈ удару, що виникає під час дорожньо-транспортної пригоди, і забезпечують збереження всередині салону залишкового життєвого простору для водія, пасажирів і зменшення аварійних навантажень, які діють на них. Відповідно до існуючих вимог і для зручності їх застосування в процесі проєктування кузовних конструкцій колісних транспортних засобів розроблено чотири критерії оцінки пасивної безпеки кузовних конструкцій. Згідно з методикою, на початковому етапі проєктування, коли ще відсутні креслення поверхонь, геометрія кузовної конструкції повинна попередньо вибиратися за ії раціональної силової схеми з урахуванням вимог пасивної безпеки і міцності самої конструкції. При цьому мають визначатися необхідні розміри конструктивних перерізів, їх співвідношення між силовими елементами. У цьому разі слід застосовувати інженерний метод розрахунку конструкцій за граничним станом, заснований на кінематичній теоремі.

У разі досягнення належного збігу результатів за окремими вузлами рекомендується продовжувати розробку кінцево-елементної моделі всієї конструкції. Паралельно належить вести підготовку до випробувань хоча б одного зразка конструкції для здійснення остаточної верифікації результатів. При їх належній збіжності отриману кінцевоелементну модель можна використовувати для оцінки пасивної безпеки конструкції в умовах дії всіх регламентованих стандартами видів аварійного навантаження. У цьому разі оцінку пасивної безпеки змінених варіантів конструкції (модифікацій базової моделі) можна вже здійснювати без проведення експериментів. Існуючі сучасні пакети програм LS-Dyna i Abaqusi дозволяють це робити на належному рівні.
\end{abstract}

Ключові слова: автомобіль, автобус, пасивна безпека, конструкція, кузов, показник, методика.

\section{Rohovskyi I. Methodological principles for determining passive safety of the wheeled vehicles body designs}

The article presents improvement of the methodological principles for determining the passive safety of body structures of wheeled vehicles by applying the finite element method. According to the methodology, the passive safety of wheeled vehicles is largely ensured by the design of their bodies and cabs. They help to absorb the main part of the impact energy that occurs in a traffic accident and ensure the preservation of the residual living space inside the cabin for the driver, passengers and reduce the emergency loads acting on them. In accordance with the existing requirements and for the convenience of their application in the process of designing the body structures of wheeled vehicles, four criteria for assessing the passive safety of body structures have been developed. According to the method, at the initial stage of design, when there are no drawings of surfaces and the geometry of the body structure must be pre-selected for its rational power scheme, taking into account the requirements of passive safety and strength of the structure. At the same time, the necessary sizes of constructive sections, their ratio between power elements have to be defined. In this case, the engineering method of calculating the structures by the boundary state, based on the kinematic theorem, should be used. In parallel, at least one design sample should be prepared for testing for final verification of the results. With their proper convergence, the obtained finite element model can be used to assess the passive safety of the structure under the conditions of all regulated by the types of emergency loads. In this case, the assessment of passive safety of the modified design options (modifications of the basic model) can already be carried out without conducting experiments. Existing modern software packages LS-Dyna and Abaqus, which allow to do it at a fairly appropriate level. according to safety requirements and finally check it at the final stage. The results of this work should be used by the relevant authorities in the certification of vehicles.

Key words: car, bus, passive safety, construction, body, indicator, technique. 
Постановка проблеми. Проблема підвищення безпеки автотранспортних засобів завжди буде актуальною, незважаючи на те, що роботи в цьому напрямі постійно ведуться [5]. На сьогодні всі новітні автомобілі відповідають існуючим вимогам пасивної безпеки [6]. Однак ці вимоги постійно вдосконалюються [10] і стають жорсткішими [8]. Відомо, що пасивна безпека автомобілів та автобусів значною мірою забезпечується конструкцією їхніх кузовів і кабін [11]. Саме вони сприяють поглинанню основної частини енергії удару, що виникає під час дорожньо-транспортної пригоди (ДТП), і забезпечують збереження всередині салону залишкового життєвого простору для водія, пасажирів та зменшення аварійних навантажень, що на них діють [4]. Тому при проєктуванні продукції автовиробник повинен передбачати запас до 30 \% їх несучої здатності для безпеки кузовної конструкції [2]. Цей запас повинен компенсувати можливе зниження іiі міцності [14] і характеристик жорсткості [9], які виникають під час експлуатації через дефекти, пошкодження і знос [12].

Аналіз останніх досліджень і публікацій. При проєктуванні кузовних конструкцій важливо, 3 урахуванням перспективи розвитку, розглядати можливість їх навантаження в різних аварійних ситуаціях [1], деякі з яких поки що навіть не передбачені існуючими стандартами, але мають важливе значення для зниження травмування та збереження життя людини. Статистика показує, що ДТП з легковими автомобілями відбуваються при зіткненнях фронтальних - $59 \%$, кососиметричних $-35 \%$, бічних $-16 \%$, наїзді на автомобіль ззаду іншого транспортного засобу - $10 \%$ i перекиданні - $23 \%$. Вантажні автомобілі беруть участь у ДТП при зіткненнях: фронтальному 3 перешкодами - 35-42\%, бічному - $10 \%$ і перекиданні - 5-15\% [3]. Найбільша тяжкість наслідків ДТП з автобусами спостерігається в разі ï перекидання, яке становить близько $20 \%$ від усіх випадків [7]. На основі матеріалів статистики розроблено чинні правила й стандарти [13]. Стосовно легкових автомобілів схеми дії на кузов аварійних навантажень за Правилами ЄЕК ООН наведені на рис. 1.

Кабіни вантажних автомобілів повинні відповідати вимогам Правил ЄЕК ООН № 29. Відповідні умови їх навантаження показані на рис. 2.

На рис. $3-5$ і в табл. $\left(F_{\mathrm{p}}-\right.$ граничне руйнівне навантаження; $E_{\text {к }}$ - енергоємність кабіни в напрямку удару) також розглянуті критерії та умови оцінки пасивної безпеки кабіни. Наведено узагальнений графік зміни аварійного навантаження, формули визначення енергоємності i руйнівного навантаження, що застосовуються в інженерному методі розрахунку.

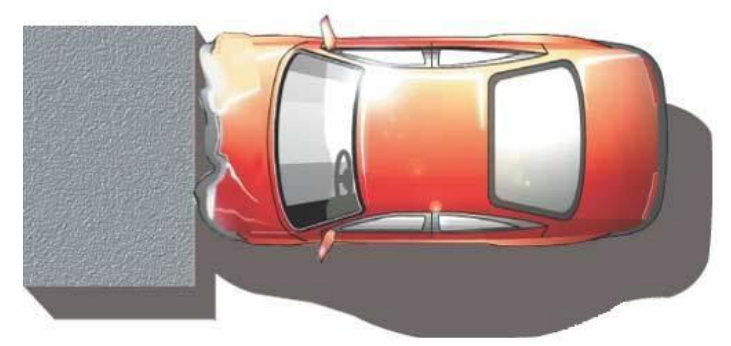

а) фронтальне зіткнення

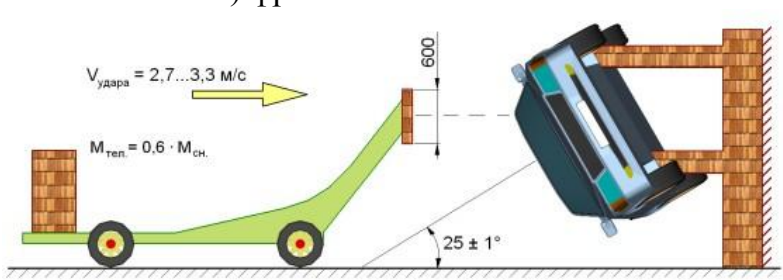

б) перекидання

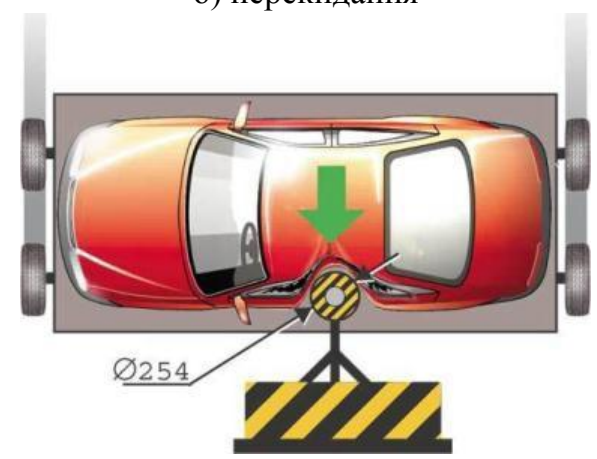

в) бічне зіткнення

Рис. 1. Схеми навантаження легкового автомобіля при випробуваннях з імітацією

Fig. 1. Schemes of car loading at simulation tests

Таблиця. Критерії i умови оцінки несучої здатності і пасивної безпеки кабіни

Table. Criteria and assessments of carrying capacity and passive safety of cabin

\begin{tabular}{|c|c|c|c|}
\hline \multirow{2}{*}{$\begin{array}{c}\text { Вид } \\
\text { наван- } \\
\text { таження }\end{array}$} & \multicolumn{2}{|c|}{ Критерії } & \multirow[b]{2}{*}{ Умова } \\
\hline & $\begin{array}{c}F_{\mathrm{p}}, \text { кН } \\
\left(\geq F_{\text {регл }}\right)\end{array}$ & $\begin{array}{l}E_{\mathrm{\kappa}}, \text { кДж } \\
\left(\geq U_{\text {регл }}\right)\end{array}$ & \\
\hline $\begin{array}{l}\text { Тип А } \\
\text { № } 29\end{array}$ & $p$ & $\begin{array}{l}U_{\text {регл }}=30 \\
\text { при } \\
M_{\text {п }}<7 \mathrm{~T} \\
U_{\text {регл }}=45 \\
\text { при } \\
M_{\text {п }} \geq 7 \mathrm{~T}\end{array}$ & \multirow{4}{*}{$\begin{array}{c}\text { Деформо- } \\
\text { ваність } \\
S_{\text {каб̆ }} \leq S_{\text {доп }} \\
\text { Залиш- } \\
\text { ковий } \\
\text { життєвий } \\
\text { простір } \\
L_{\text {каб }} \geq L_{\text {доп }}\end{array}$} \\
\hline $\begin{array}{l}\text { Тип В } \\
\text { № } 29 \\
\end{array}$ & $\begin{aligned} F_{\text {регл }} & =M_{\text {п }} g \\
& \leq 100\end{aligned}$ & - & \\
\hline $\begin{array}{l}\text { Тип С } \\
\text { № } 29\end{array}$ & $F_{\text {регл }}=0,2 M_{\text {п }} g$ & - & \\
\hline Швеція & & $U_{\text {регл }}=30$ & \\
\hline
\end{tabular}




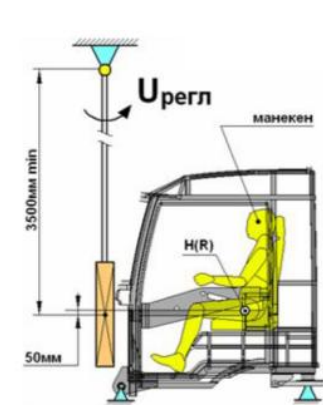

Tin A
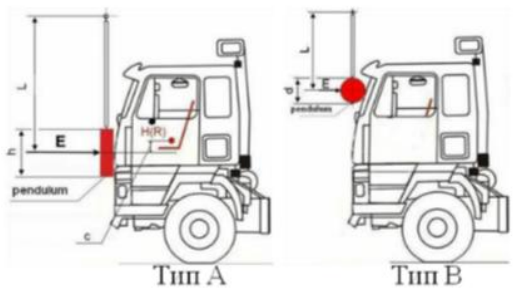

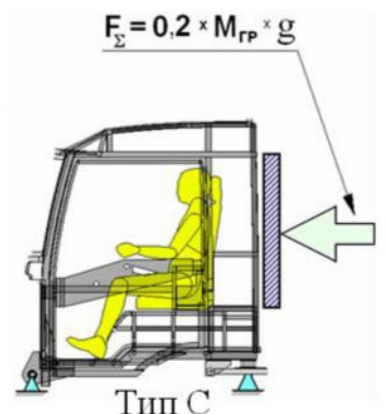

Тип C

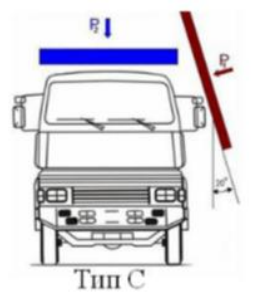

Рис. 2. Схеми навантаження кабін вантажного автомобіля при випробуваннях з імітацією

Fig. 2. Schemes of of a truck cabin loading at simulation tests

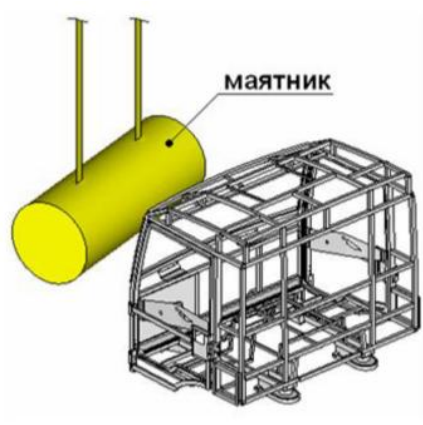

Рис. 3. Схеми навантаження кабін вантажного автомобіля при випробуваннях із маятником

Fig. 3. Schemes ofa truck cabins loading at tests with a pendulum

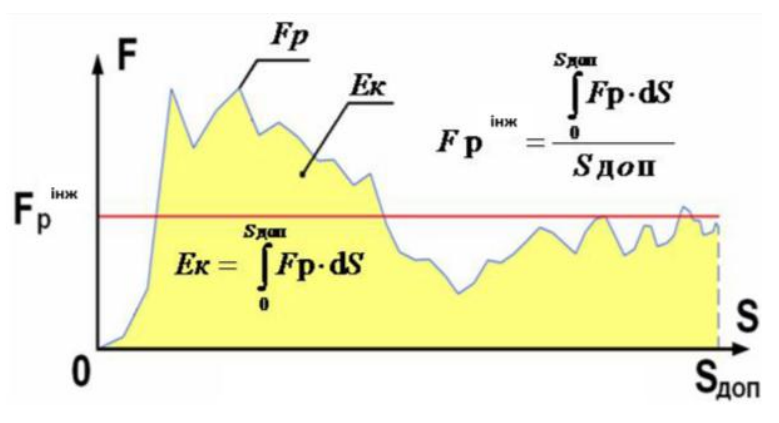

Рис. 4. Зміна аварійного навантаження

Fig. 4. Emergency delivery service

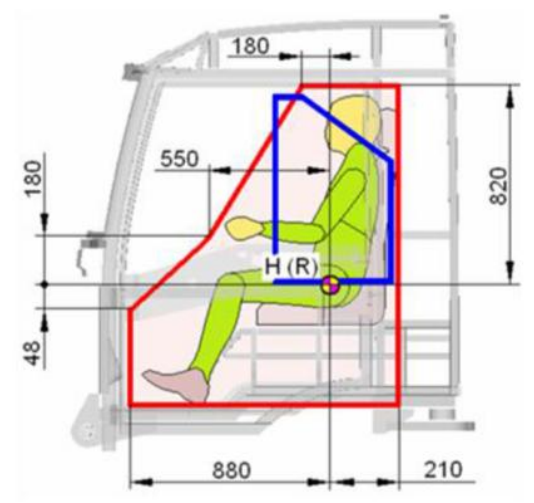

Рис. 5. Схема кабіни і залишкового життєвого простору

Fig. 5. Scheme of cabin and surplus living space 

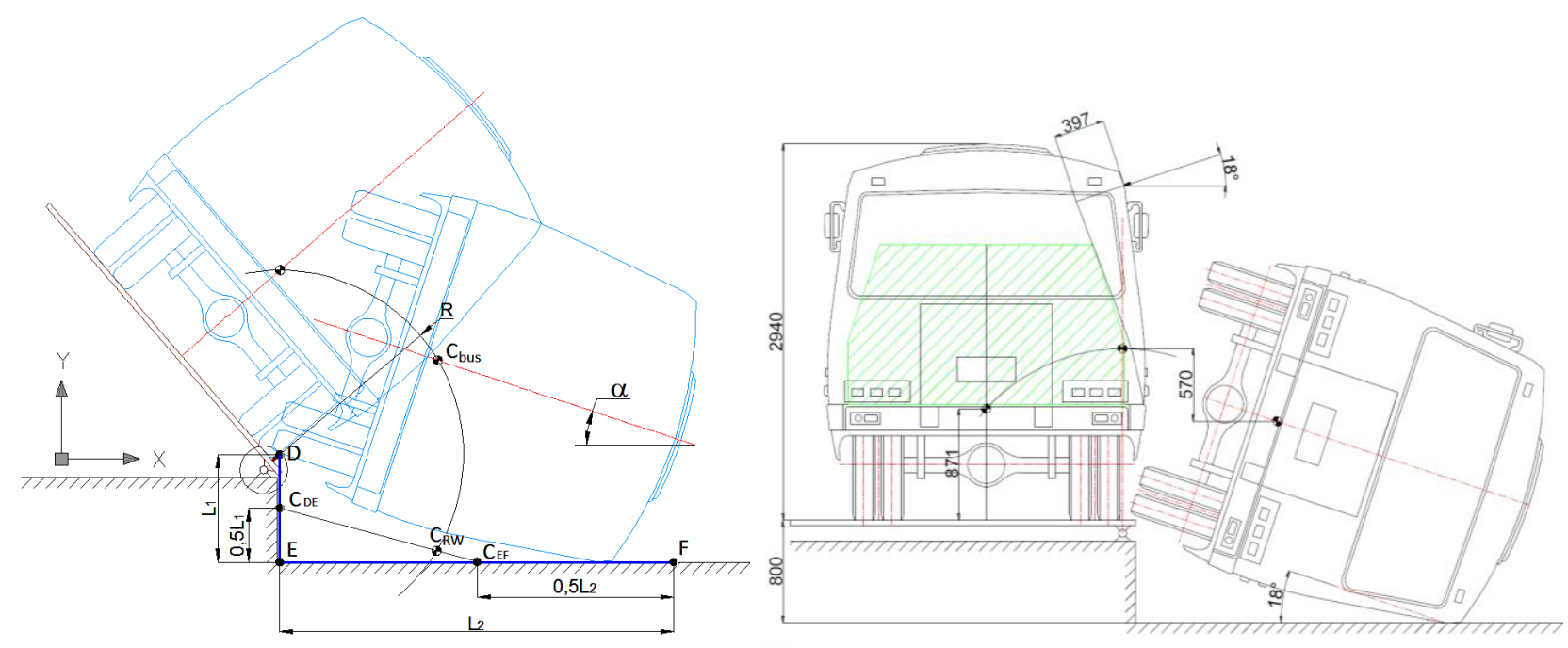

Рис. 6. Схема випробування автобуса на перекидання

Fig. 6. Scheme of a bus rollover test

Для автобусів Правилами СЕК ООН № 66 обумовлюються умови їх випробування і розрахунків на перекидання 3 уступу заввишки 0,8 м (рис. 6).

Постановка завдання. Метою досліджень $\epsilon$ вдосконалення методичних засад визначення пасивної безпеки кузовних конструкцій колісних транспортних засобів за допомогою застосування методу кінцевих елементів за реалізації сучасних пакетів програм LS-Dyna i Abaqus.

Виклад основного матеріалу. Відповідно до існуючих вимог і для зручності їх застосування в процесі проєктування кузовних конструкцій розроблені критерії оцінки пасивної безпеки кузовних конструкцій:

1. Енергоємність конструкції в напрямку дії аварійного навантаження $E_{\mathrm{K}}$.

2. Опір конструкції руйнуванню, який характеризує руйнівне навантаження $F_{\mathrm{p}}$, граничне за текучістю навантаження $F_{\text {т. }}$.

3. Деформованість конструкції S в напрямку дії аварійного навантаження, за допустимої деформації $S_{\text {доп, }}$ зі збереженням залишкового простору $L_{\text {зал. }}$.

4. Перевантаження конструкції за рівнем уповільнення $j_{\max }$ i швидкості наростання уповільнення $V_{j}$.

Особливий інтерес становить порівняльний аналіз поведінки спрощеної і детальної кінцевоелементних моделей усього кузова автобуса в умовах, що імітують перекидання. На рис. 6 показана схема перекидання автобуса відповідно до Правил СЕК ООН № 66. Центр мас автобуса
$\mathrm{C}_{\text {bus }}$ перед контактом iз жорсткою плитою здійснює обертальний рух. Припустивши, що центр мас автобуса буде рухатися за кругової траєкторії радіуса R як до удару, так і після нього, була запропонована еквівалентна схема навантаження, що імітує перекидання автобуса. У цьому разі модель каркаса автобуса деформується під дією енергії жорсткої стінки, здійснює обертальний рух. У цьому випадку центр мас навантажувальної плити $\mathrm{C}_{\mathrm{RW}}$ повинен повторювати траєкторію дуги радіусом R. Необхідне положення $\mathrm{C}_{\mathrm{RW}}$ може бути досягнуто зміною геометричних і фізичних властивостей жорсткої плити, зокрема за рахунок варіювання маси ділянок DE i EF.

Пропоновані критерії узгоджуються 3 умовами існуючих вимог і можуть використовуватися під час проєктування, доведення і сертифікації конструкцій для проведення розрахунково-експериментальних оцінок їх пасивної безпеки.

Енергоємність конструкції $E_{\text {к }}$ (див. рис. 4) визначається роботою, яку здійснює руйнівне навантаження $F_{\mathrm{p}}$ на шляху деформації конструкції в допустимих межах $S_{\text {доп: }}$ :

$$
E_{k}={ }_{0}^{S_{\text {доп }}} F_{p} d S \text {. }
$$

Допустима деформація $S_{\text {доп }}$ визначається як різниця між геометричними розмірами салону кузова або кабіни i розмірами внутрішнього залишкового простору, який повинен зберігатися в салоні в разі аварії. Фактично $S_{\text {доп }}$ - це траєкторія руху вектора навантаження від вихідного початкового контуру салону до межі залишкового простору. 
Руйнівне навантаження $F_{\mathrm{p}}$ (див. рис. 4) характеризує стійкість конструкції до руйнування. Цьому навантаженню відповідає перетворення моделі в кінематичний пластичний механізм.

Граничне за текучістю навантаження $F_{\mathrm{T}}-$ навантаження, при якому з'являється текучість у крайніх волокнах перерізу найслабшого силового елементу.

Розроблені критерії дозволяють оцінювати властивості конструкції, що визначають ії пасивну безпеку. Оцінка пасивної безпеки конструкції ведеться з розгляду, як правило, двох або трьох критеріїв. Один із них взаємопов'язаний із режимом навантаження, а інші - 3 вимірюваними параметрами. Конструкція вважається безпечною в тому разі, якщо виконуються умови пасивної безпеки:

$$
\begin{gathered}
E_{k} \geq E_{\text {регл }}=U_{\text {регл }} ; F_{p} \geq F_{\text {регл }} ; F_{T} \geq F_{\text {регл }} ; \\
S \leq S_{\text {доп }}=\Delta_{\text {регл }} ; L_{\text {зал }} \geq L_{\text {регл }} ; \\
j_{\text {max }} \leq j_{\text {доп }} ; V_{j} \leq V_{\text {јдоп }} .
\end{gathered}
$$

Для безпечної конструкції повинні виконуватися як мінімум дві умови при розгляді статичного режиму навантаження і три - при ударній дії навантаження. Вони дозволяють оцінювати працездатність кузовів і кабін протягом усього процесу проєктування - від вибору безпечних силових схем до завершальних етапів. При цьому повинні застосовуватися як розрахункові, так і експериментальні методи оцінки. Структурна схема розробленої методики розрахунково-експериментальної оцінки несучої здатності за руйнівним навантаженням i пасивної безпеки містить шість етапів:

Етап 1. Вибір безпекової силової схеми конструкції. Підбір характеристик силових елементів. Визначення механізму руйнування за умови $F_{p} \geq F_{\text {регл. }}$

Етап 2. Розробка кінцево-елементних моделей окремих ділянок. Розрахунок моделей окремих ділянок конструкції.

Етап 3. Випробування зразків окремих ділянок конструкції, силових елементів і зразків матеріалів. Порівняльна оцінка результату та експерименту.

Етап 4. Розробка детальної кінцево-елементної моделі конструкції. Розрахунок детальної моделі та оцінка іï несучої здатності.

Етап 5. Випробування конструкції в умовах одного 3 видів аварійного навантаження. Верифікація результатів випробування.
Етап 6. Оцінка пасивної безпеки конструкції кузова. Безпекова конструкція за досягнення умов $E_{k} \geq E_{\text {регл }}=U_{\text {регл }} ; \quad F_{p} \geq F_{\text {регл }} ; \quad F_{T} \geq F_{\text {регл }} ;$ $S \leq S_{\text {доп }}=\Delta_{\text {регл } ;} \quad L_{\text {зал }} \geq L_{\text {регл }} ; \quad j_{\max } \leq j_{\text {доп }} ;$

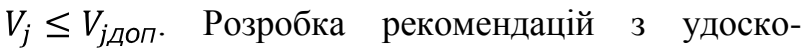
налення конструкції за недосягнення хоча б однієї 3 умов $E_{k} \geq E_{\text {регл }}=U_{\text {регл }} ; F_{p} \geq F_{\text {регл }} ; F_{T} \geq F_{\text {регл }}$; $S \leq S_{\text {доп }}=\Delta_{\text {регл} ;} ; \quad L_{\text {зал }} \geq L_{\text {регл} ;} ; \quad j_{\max } \leq j_{\text {доп } ;}$

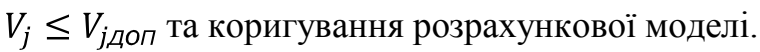

Відповідно до методики, на початковому етапі проєктування, коли ще відсутні креслення поверхонь, геометрія кузовної конструкції повинна попередньо вибиратися за їі раціональної силової схеми 3 урахуванням вимог пасивної безпеки і міцності самої конструкції. При цьому повинні визначатися необхідні розміри конструктивних перерізів, їх співвідношення між силовими елементами. У цьому разі належить застосовувати інженерний метод розрахунку конструкцій за граничним станом, заснований на кінематичній теоремі. Вона дає змогу досить ефективно розглядати всі можливі механізми руйнування силової схеми і її варіантів зміни за різного впливу квазістатичних аварійних навантажень і вибирати 3 них найбезпечніший.

Після попереднього вибору силової схеми конструкції, розробки поверхонь, панелей i каркаса (якщо він повинен бути) проєктувальник може отримати необхідну інформацію для формування кінцево-елементних моделей окремих вузлів i ділянок, силових перерізів і секцій. Розробка таких моделей, їх розрахунок, виготовлення дослідних зразків та їх випробування, порівняльна оцінка результатів розрахунків і експерименту $\epsilon$ невід'ємною частиною процесу формування детальної кінцево-елементної моделі всієї кузовної конструкції. Такі дослідження корисні для проведення верифікації результатів; обгрунтування правомірності використовуваних принципів, підходів вибору кінцево-елементної моделі і виконання комп'ютерного моделювання; уточнення характеристик матеріалів, коефіцієнтів тертя й інших параметрів. Це підтверджують проведені розрахунково-експериментальні дослідження вузла зв'язку стійки лобового вікна кабіни 3 петельною стійкою, результати яких показані на рис.7, а також раніше проведені розрахунки i випробування секцій кузова автобуса. 


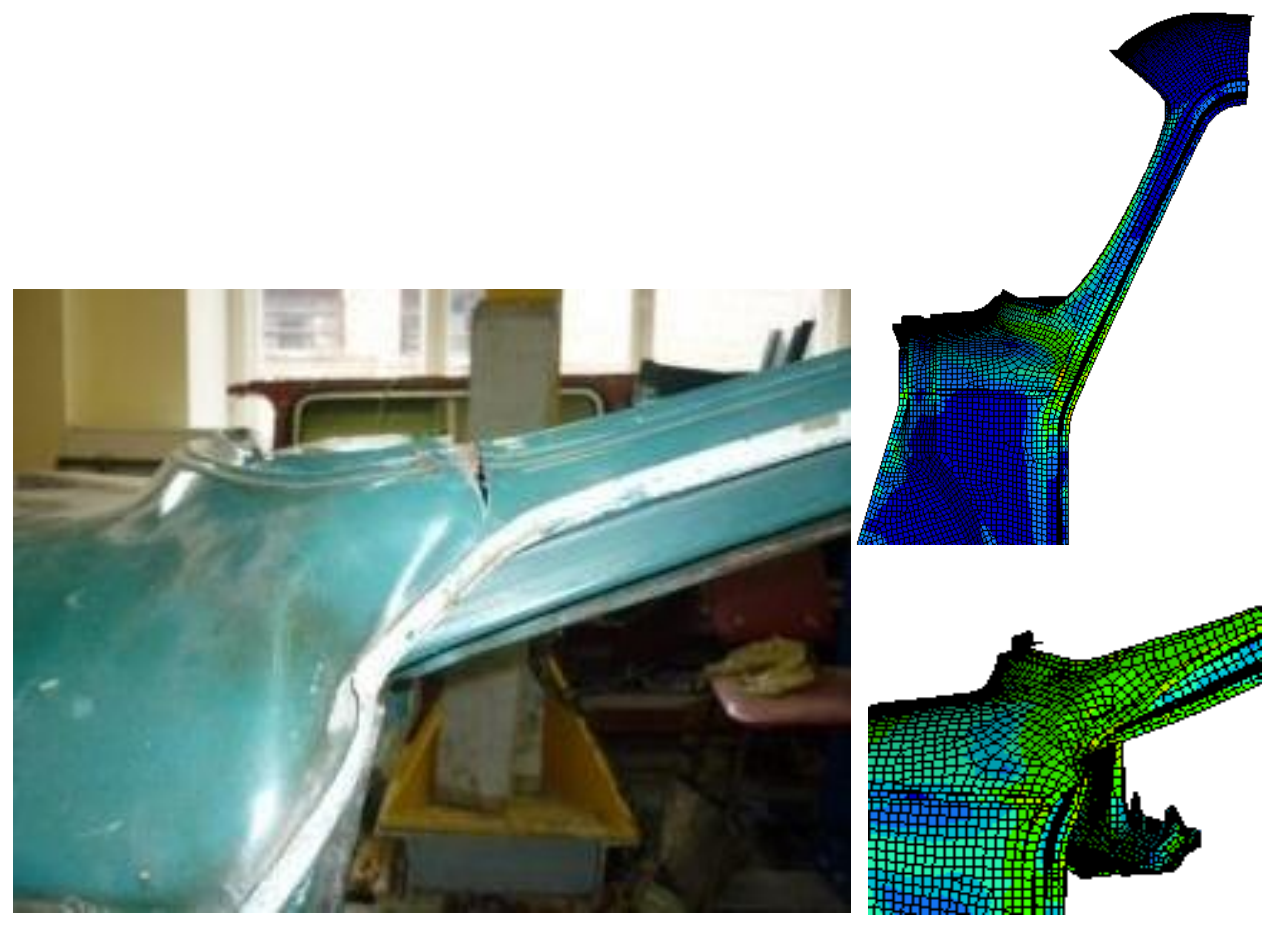

Рис. 7. Розрахунково-експериментальні дослідження вузла зв'язку стійки лобового вікна кабіни з петельною стійкою

Fig. 7. Computational and experimental studies of communication node of cab front rack with hinged rack

У разі досягнення належного збігу результатів за окремими вузлами можна продовжувати розробку кінцево-елементної моделі всієї конструкції. Паралельно слід вести підготовку до випробувань хоча б одного зразка конструкції для проведення остаточної верифікації результатів. При їх належній збіжності отриману кінцевоелементну модель можна використовувати для оцінки пасивної безпеки конструкції в умовах дії всіх регламентованих стандартами видів аварійного навантаження. У цьому разі оцінку пасивної безпеки змінених варіантів конструкції (модифікацій базової моделі) можна вже здійснювати без проведення експериментів. Існуючі сучасні пакети програм, наприклад, LS-Dyna, Abaqus дають змогу це робити на досить належному рівні. На рис. 8 показані результати розрахунку кузова за дії аварійного навантаження, що імітує умови, які виникають при перекиданні легкового автомобіля.

Встановлено, що для підвищення пасивної безпеки легкових автомобілів необхідно проєктувати їх енергоємні передні і задні частини з метою забезпечення поглинання енергії удару. Середня частина (салон) повинна бути відносно міцною, твердою i забезпечувати збереження всередині залишкового життєвого простору для водія i пасажирів за всіх можливих аварійних ситуацій. Це можна здійснити за наявності міцних порогів, передньої, задньої і центральної стійок, силових елементів даху, розташованих за периметром, надвіконних поясів, поясів між центральними стійками і їх жорстких зв'язків між собою. Будьякі конструктивні зміни і заходи повинні бути спрямовані на зниження тяжкості наслідків ДТП та збереження життя людини.

На рис. 9 показано випробування безкаркасної кабіни вантажного автомобіля при вертикальному навантаженні, ii напружено-деформований стан, отриманий за допомогою комп'ютерного моделювання, і приклад порівняльної оцінки результатів розрахунку та експерименту.

Результати комп'ютерного моделювання каркасної кабіни показані на рис. $10-12$. При цьому проведені дослідження впливу виду моделі на результат розрахунку - порівняння результатів стрижневої моделі з детальною. Видно, що в разі великих пластичних деформацій стрижнева модель дає завищені значення руйнівного навантаження, тому іiі можна використовувати під час проведення різноманітних досліджень і порівняльних оцінок. 

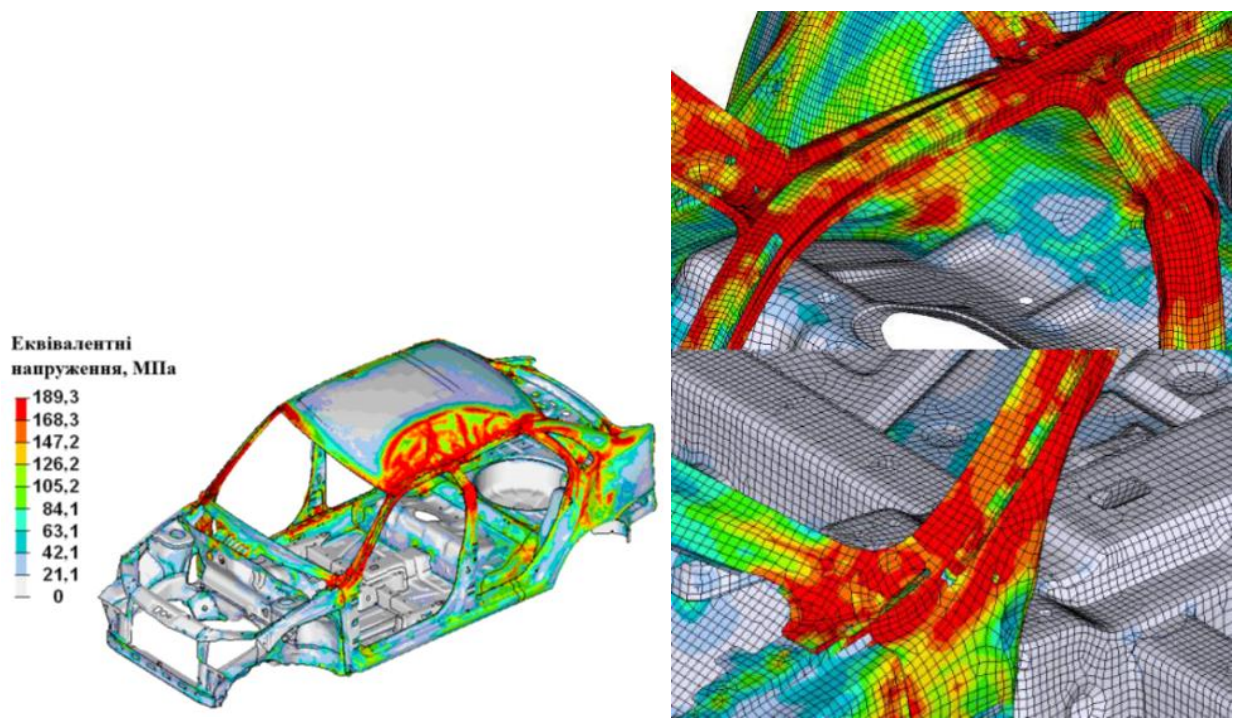

Рис. 8. Моделі деформованого кузова та графіки зміни навантаження і переміщення

Fig. 8. Deformed body models and graphs of load and displacement changes
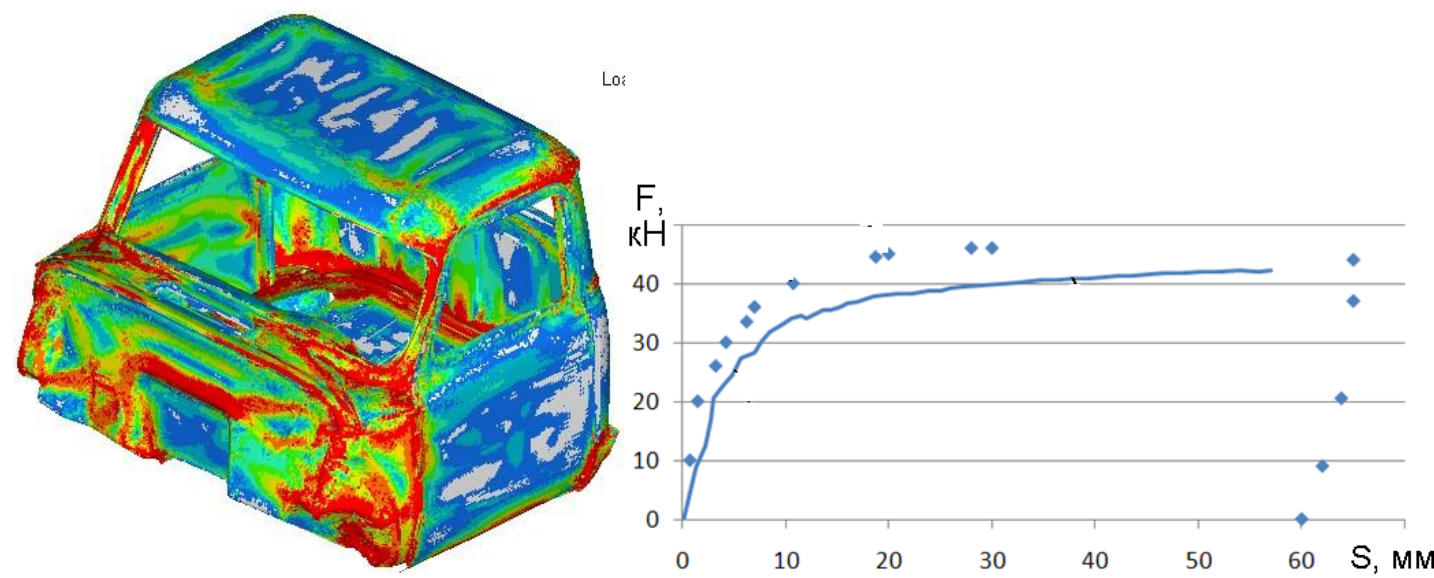

Рис. 9. Напружено-деформований стан безкаркасної кабіни вантажного автомобіля за вертикального навантаження

Fig. 9. Stress-strain state of a frameless truck cab under vertical loading

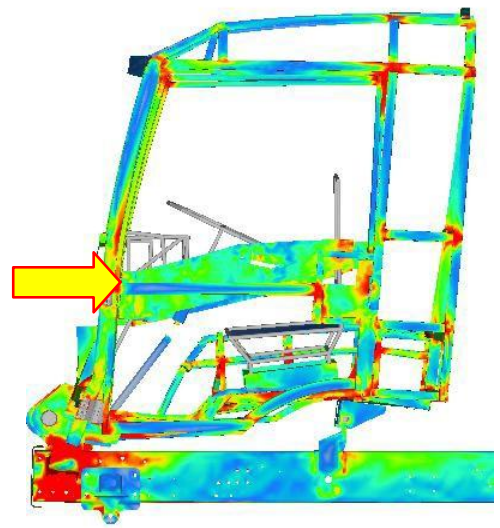

Рис. 10. Напружено-деформований стан моделі кабіни

при ударному навантаженні маятником спереду

Fig. 10. Stress-strain state of cabin model under shock loading by pendulum in front 

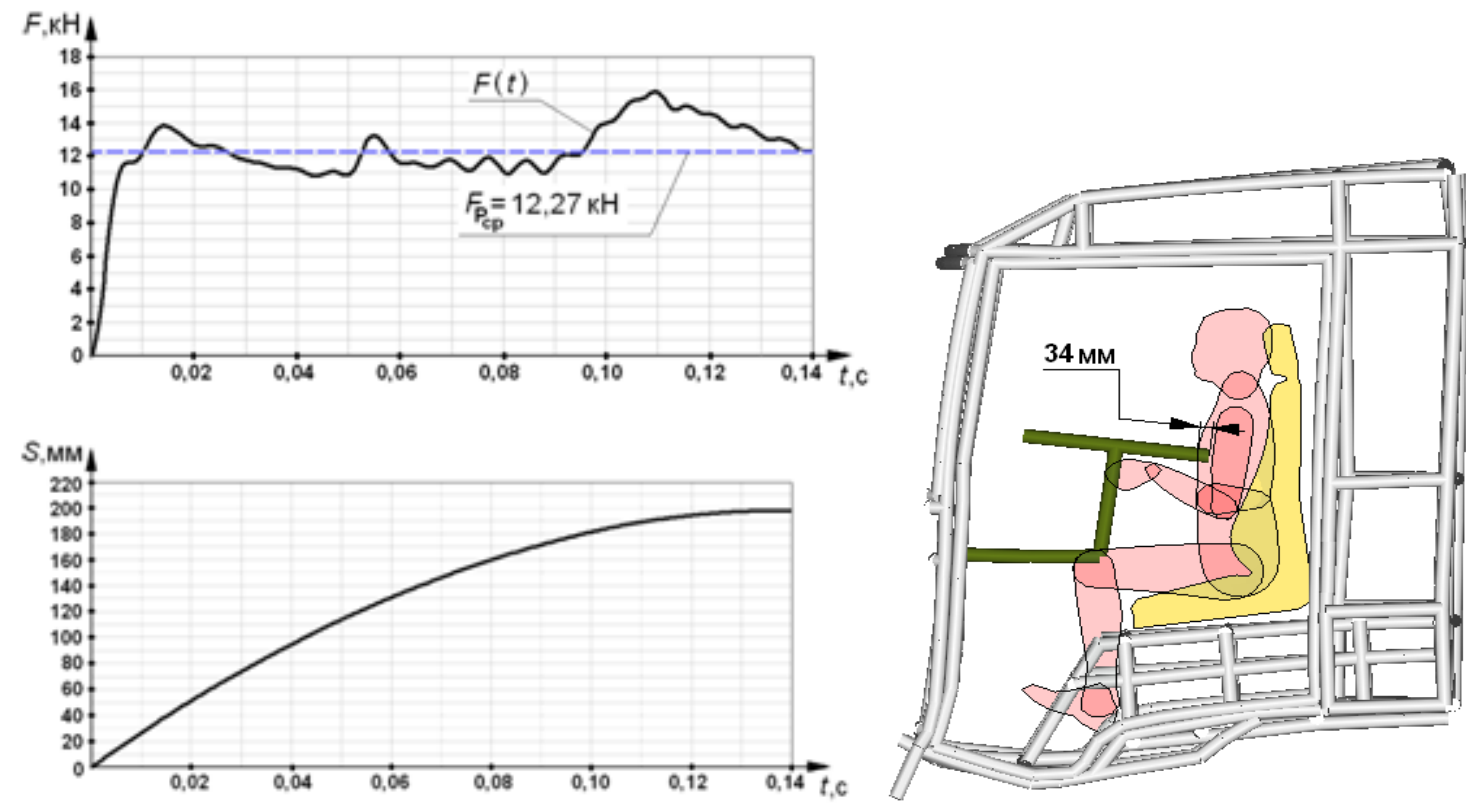

Рис. 11. Оцінка залишкового життєвого простору в кабіні з розміщенням манекена

Fig. 11. Assessment of residual living space in cockpit by dummy placement

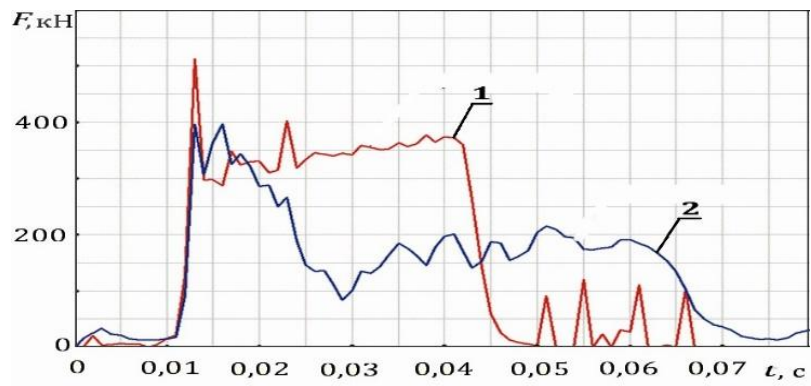

Рис. 12. Графік зміни ударного навантаження: 1 - стрижнева модель; 2 - детальна модель Fig. 12. Impact load change graph: 1 - bar model; 2 - detailed model

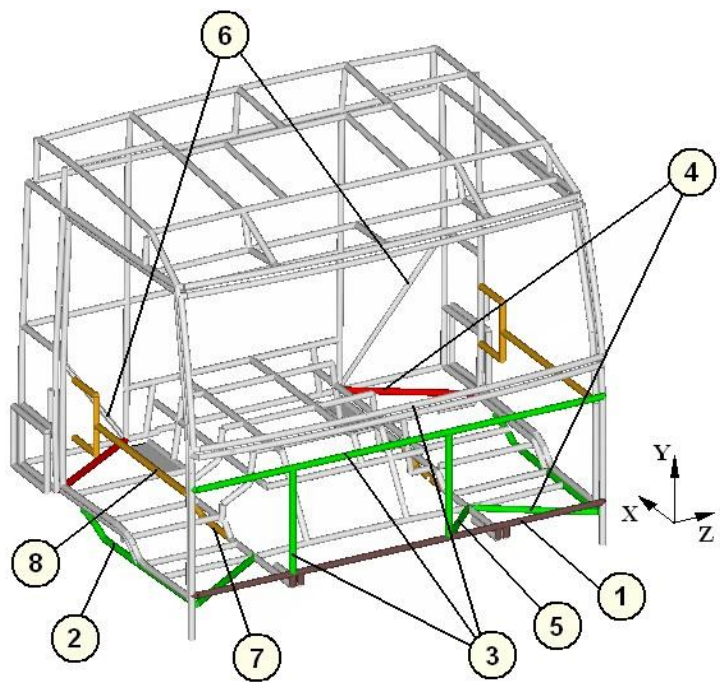

Рис. 13. Елементи, що підвищують безпеку кабіни

Fig. 13. Elements that increase the cab safety 

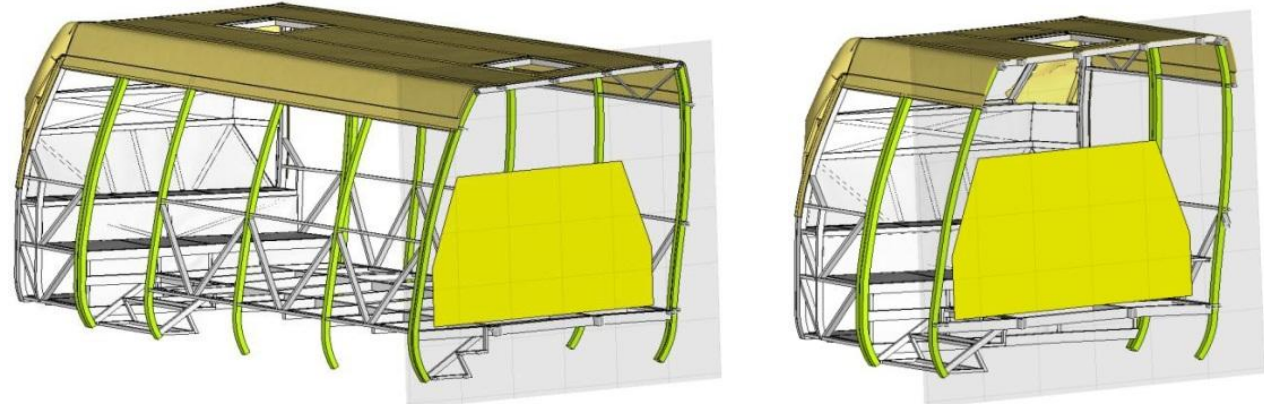

Рис. 14. Моделі деформованого кузова і задньої секції автобуса

Fig. 14. Models of the deformed body and back section of bus

Встановлено, що підвищенню безпеки кабін сприяють (див. рис. 13): посилення нижнього переднього бруса підстави (поз. 1); збільшення перерізів (не менше $60 \times 40 \times 3$ ) порогів, підвіконного поясу і вертикальних стійок передньої частини (поз. 2 і поз. 3); введення підсилювальних розкосів у задніх і передніх кутах підстави кабіни (поз. 4 i поз. 5) і розкосів у задній стінці кабіни (поз. 6); посилення поздовжніх лонжеронів підстави (поз. 7); введення брусів безпеки у дверях (поз. 8).

Деформовані види кузова автобуса і його задньої секції зі зонами залишкового життєвого простору показані на рис. 14. На підставі проведених досліджень підтверджено відоме положення про те, що безпеку кузовів автобусів можна оцінювати за результатами розрахунків та випробувань його окремих секцій, застосовуючи для цього розрахунково-експериментальний метод.

Встановлено, що безпека кузовів автобусів підвищується за наявності всередині салону перегородок і стійок поручнів, при жорсткому з'єднанні каркасів сидінь із боковинами. Підвищенню безпеки сприяє наявність такого каркаса кузова, в якого в разі перекидання автобуса зони пластичних деформацій перерізів (пластичні шарніри) вертикальних силових елементів боковин виникають якомога вище від основи кузова.

Висновки. Комп'ютерне моделювання на основі методу кінцевих елементів із використанням детальної кінцево-елементної моделі дає змогу отримувати уточнені результати, необхідні для оцінки пасивної безпеки кузовних конструкцій на завершальному етапі проєктування.

Розроблені критерії дозволяють оцінювати властивості конструкції, що визначають ії пасивну безпеку. Оцінка пасивної безпеки конструкції ведеться на підставі розгляду, як правило, двох або трьох критеріїв. Один із них взаємопов'язаний iз режимом навантаження, а інші - 3 вимірюваними параметрами. Конструкція вважається безпечною в тому разі, якщо виконуються умови пасивної безпеки: $E_{k} \geq E_{\text {регл }}=U_{\text {регл }} ; F_{p} \geq F_{\text {регл }}$; $F_{T} \geq F_{\text {регл }} ; \quad S \leq S_{\text {доп }}=\Delta_{\text {регл }} ; \quad L_{\text {зал }} \geq L_{\text {регл }} ;$ $j_{\text {max }} \leq j_{\text {доп }}$

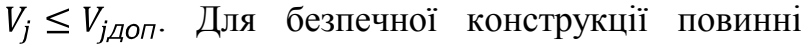
виконуватися як мінімум дві умови при розгляді статичного режиму навантаження і три - при ударній дії навантаження. Вони дають змогу оцінювати працездатність кузовів і кабін протягом усього процесу проєктування - від вибору безпечних силових схем до завершальних етапів. При цьому повинні застосовуватися як розрахункові, так і експериментальні методи оцінки. Структурна схема розробленої методики розрахунково-експериментальної оцінки несучої здатності за руйнівним навантаженням i пасивної безпеки містить шість етапів.

Встановлено, що безпека кузовів автобусів підвищується за наявності всередині салону перегородок і стійок поручнів, при жорсткому з'єднанні каркасів сидінь із боковинами. Підвищенню безпеки сприяє наявність такого каркаса кузова, в якого в разі перекидання автобуса зони пластичних деформацій перерізів (пластичні шарніри) вертикальних силових елементів боковин виникають якомога вище від основи кузова.

Розглянуті матеріали роботи можуть бути корисні для фахівців, що займаються проєктуванням кузовних конструкцій автотранспортних засобів та оцінкою їх пасивної безпеки.

\section{Бібліографічний список}

1. Brylev I., Evtiukov S., Evtiukov S. Problems of calculating the speed of two-wheeled motor vehicles in an accident. Transportation Research Procedia. 2018. Vol. 36. P. 84-89. doi:10.1016/j.trpro.2018.12.047. 
2. Development of a system for determining the informativeness of the diagnosing parameters of the cylinder-piston group of the diesel engines in operation / A. Hrynkiv et al. Eastern-European Journal of Enterprise Technologies. 2020. Vol. 3 (5(105)). P. 19-29. doi:10. 15587/1729- 4061.2020.206073.

3. Evtiukov S., Karelina M., Terentyev A. A method for multi-criteria evaluation of the complex safety characteristic of a road vehicle. Transportation Research Procedia. 2018. Vol. 36. P. 149-156. doi: 10.1016/j.trpro. 2018.12.057.

4. External rolling of a polygon on a closed curvilinear profile / T. Kresan et al. Acta Polytechnica. 2020. Vol. 60, No. 4. P. 313-317. doi: 10.14311/ AP.2020.60.0313.

5. Hashemi S. M. Strength of Super-Structure UN-ECE R66 Rollover Approval of Coaches based on Thin-Walled Framework Structures. Vehicle Structures \& Systems. 2019. № 1(4). P. 78-84.

6. He Y., McPhee J. A design methodology for mechatronic vehicles: Application of multidisciplinary optimization, multibody dynamics and genetic algorithms. Vehicle System Dynamics. 2019. Vol. 43, issue 10. P. 697733. doi:10.1080/00423110500151077.

7. Marusin A., Marusin A., Danilov I. A method for assessing the influence of automated traffic enforcement system parameters on traffic safety. Transportation Research Procedia. 2018. Vol. 36. P. 500-506. doi: 10.1016/j.trpro. 2018.12.136.

8. Modeling the weight of criteria for determining the technical level of agricultural machines / I. L. Rogovskii ey al. IOP Conference Series: Earth and
Environmental Science. 2021. Vol. 677. P. 022100. doi: 10.1088/1755-1315/677/2/022100

9. Safiullin R., Marusin A., Safiullin R., Ablyazov T. Methodical approaches for creation of intelligent management information systems by means of energy resources of technical facilities. E3S Web of Conferences. 2019. Vol. 140. P. 10008. doi: 10.1051/ e3sconf/2019140100 08.

10. Saplinova V., Novikov I., Glagolev S. Design and specifications of racing car chassis as passive safety feature. Transportation Research Procedia. 2020. Vol. 50. P. 591-607. doi: 10.1016/j.trpro.2020.10.071.

11. Study of stability of modes and parameters of motion of vibrating machines for technological purpose / I. Nazarenko et al. Eastern-European Journal of Enterprise Technologies. 2020. Vol. 6(7-108). P. 71-79. doi: 10.15587/1729-4061.2020.217747.

12. Studying truck transmission oils using the method of thermal-oxidative stability during vehicle operation / V. Aulin et al. Eastern-European Journal of Enterprise Technologies. 2019. Vol. 1 (1/6(97)). P. 6-12. doi: 10.15587/1729-4061.2019.156150.

13. The ways of effectiveness increase of liquid fuel with organic addition appliance in transportation / S. Soo et al. Advances in Transportation Sciences. 2020. Vol. 170. P. 833-838.

14. Voinalovych O., Hnatiuk O., Rogovskii I., Pokutnii O. Probability of traumatic situations in mechanized processes in agriculture using mathematical apparatus of Markov chain method. Engineering for Rural Development. 2019. Vol. 18. P. 563-269. doi: 10.22616/ERDev2019.18. N245. 